\title{
観血的治療を要した腎血管性高血圧の検討
}

\author{
古賀 千穂 ${ }^{1}$, 藤田 秀樹 ${ }^{1}$, 田中 敏克 ${ }^{1)}$, 富永 健太 ${ }^{1)}$, \\ 亀井 直哉 ${ }^{1)}$, 小川 禎治 ${ }^{1}$, 佐藤 有美 ${ }^{1)}$, 城戸佐知子 ${ }^{1)}$, \\ 大嶋 義博2) \\ 兵庫県立こども病院循環器科1，，心臟血管外科22
}

Keywords :

renovascular hypertension,

percutaneous transluminal renal

angioplasty

\section{Renovascular Hypertension with Renal Artery Intervention in Children}

Chiho Koga ${ }^{1)}$, Hideki Fujita ${ }^{1)}$, Toshikatsu Tanaka ${ }^{1)}$, Kenta Tominaga ${ }^{1)}$, Naoya Kamei ${ }^{1)}$,

Yoshiharu Ogawa $^{1)}$, Yumi Sato ${ }^{1)}$, Sachiko Kido ${ }^{1)}$, Yoshihiro Oshima ${ }^{2)}$

Departments of ${ }^{1)}$ Cardiology, ${ }^{2)}$ Cardiovascular Surgery, Kobe Children's Hospital, Kobe, Japan

Background: Secondary hypertension is more common in children than in adults. Although the number of patients with renal artery stenosis is relatively small, renal artery stenosis is an important clinical condition because of the potential for a complete cure.

Methods: We reviewed the clinical outcomes of patients with renovascular hypertension who underwent percutaneous transluminal angioplasty or surgery at a single center between 2005 and 2011. The hypertensive response was defined as (1) cured : normal blood pressure with no antihypertensive treatment, (2)improved : improved blood pressure with identical or reduced treatment, (3) unchanged : no change in blood pressure despite angiographic success, or (4) failed.

Results: The first surgical or endovascular intervention was performed between 1.8 and 13 years of age. Nineteen renal angioplasty procedures and four surgeries were done. The outcomes were as follows : cured in one patient who underwent surgery, improved in 14 patients who underwent renal angioplasty and three who underwent surgery, unchanged in four patients who underwent renal angioplasty, and failed in one patient who underwent renal angioplasty.

Conclusions: The results as a whole were satisfactory. The treatment of small children and patients with double renal arteries is difficult because of their small vessels.

\section{要 旨}

背景：腎血管性高血圧は二次性高血圧であり, 原因である腎動脈狭窄を解除することにより改善を得られる可能性 が高い

対象および方法：腎血管性高血圧と診断され，2005〜 2011 年までに当院で観血的治療を行った小児 9 例について 検討した. 治療結果は(1)治癒：薬物治療なしで正常血圧を保てるもの, (2)改善：同量か減量した薬物治療で収縮期 もしくは拡張期血圧が低下したもの, (3)降圧効果なし：血管造影では狭窄は改善したが血圧に変化がみられなかっ たもの, (4)無効 : 狭窄血管を拡張できなかったものの 4 型に分けて評価した.

結果：初回観血的治療介入時期は 18 カ月〜 13 歳であった. カテーテル治療は 19 回, 8 例に施行し, 外科治療は 4 例 に施行した。治療結果は, 治癒は外科治療で 1 例, 改善はカテーテル治療で 14 回, 外科治療で 3 例, 降圧効果なしは カテーテル治療で 4 回, 無効はカテーテル治療で 1 回であった.

結論：カテーテル治療, 外科治療ともに短期の成績は㧍おむね良好であったが, 幼児や重複腎動脈で細径のステン 卜留置に至った場合は, 再狭窄に対して繰り返し介入が必要となり, 治療に難渋した.

2013 年 9 月 18 日受付

2014 年 1 月 31 日受理
別刷請求先：干 654-0081 神戸市須磨区高倉台 1-1-1

兵庫県立こども病院循環器科 古賀 千穂 


\section{はじめに}

小児では 1 〜 $\%$ に高血圧がみられ，腎血管性高血 圧はそのうち $5 \sim 10 \%$ を占める ${ }^{1)}$. 小児にみられる腎 血管性高血圧の原疾患としては線維筋性異形成, 高安 病, 神経線維腫症が多い2)。その治療方法としては薬物 治療, カテーテル治療, ならびに外科治療があり, 腎虚 血による腎機能低下を来さないためにカテーテル治療 や外科治療で腎血流を回復させることが望ましい，た だ腎動脈が細い例ではカテーテル治療, 外科治療とも に容易ではないため, 乳幼児や重複腎動脈の例では治 療選択に難渋することが多い.

今回われわれは, 当院で観血的治療を行った腎血管 性高血圧症例の治療経過を後方視的に検討した.

\section{対象と方法}

腎血管性高血圧と診断され, 2005 年 2 月～ 2011 年 4 月までに当院で観血的治療を行った小児患者 9 例 (男 児 7 例, 女児 2 例) を対象とした。患者の詳細や血圧, 診断, 検査, 治療方法を診療記録から後方視的に検討 した。

高血圧の定義は Update on the 1987 Task Force Report on High Blood Pressure in Children and Adolescents に基 づき性, 年齢, 身長による正常值の $95 \%$ tile 以上とし た. 腎血管病変の診断は腹部エコー, 腎レノグラム, カ プトプリル負荷腎レノグラム, 造影 CT, MRA, 腹部血 管造影検查, 分腎レニン活性測定により行った. カテー テル治療または外科治療の術前検査として全例血管造 影検査を行った.

治療は小児循環器内科, 小児腎臓内科, 小児心臓血 管外科が担当した，腹部血管造影による形態的評価で カテーテル治療が可能と判断された場合は外科治療よ りカテーテル治療を優先した. 経皮的バルーン血管形 成術が有効でなかった例にはステント留置やカッティ ングバルーンを選択的に行って㧍り，ステントは 2007 年以降に, カッティングバルーンは 2009 年に当院で腎 動脈に対して使用した。 ステント留置はバルーン血管 形成術直後に recoil を来した例, 短期間に反復してバ ルーン血管形成術を必要とした例に行った. カテーテ ル治療が有効でなかった場合には外科治療を選択し た. 治療結果としては Ellis らや Shroff らの提案するも のを参考とし, (1)治癒：薬物治療なしで正常血圧 $(95 \%$ tile 以下)を保てるもの, (2)改善: 同量か減量した薬物 治療で収縮期もしくは拡張期血圧が低下したもの, (3) 降圧効果なし：血管造影では狭窄は改善したが血圧に
変化がみられなかったもの, (4)無効：狭窄血管を拡張 できなかったものの 4 型に分類した。

降圧薬の選択, 調整扔よび介入の必要性の判断は主 に小児腎臟内科が行い, カテーテル治療を行った例や 外科治療を行った例のフォローアップには，それぞれ 小坚循環器科, 小览心臓血管外科が協力して行った。

\section{結 果}

腎血管性高血圧と診断された年齢は 16 カ月〜 13 歳 で中央值は 4 歳であった. 基礎疾患はもやもや病が 4 例, 神経線維腫症 1 型が 1 例であった。両側重複腎動 脈の合併例が 1 例であった。脳血管病変を合併してい たのは 5 例で, もやもや病の 4 例のうち 2 例はカテー テル治療の前に脳血管バイパス術を受けていた，診断 前に有症状であったのは 1 例で, 頭痛, 悪心, 嘔吐, け いれんがみられ，頭部 CT で皮質下出血があった，それ 以外の児はほかの疾患で入院もしくは外来受診時に高 血圧を指摘され診断に至った。

診断のために造影 CT 5 例, 腹部エコーを 4 例, MRI 1 例で施行し, 形態的評価を行った。レノグラ ムは6例に行った。もやもや病児で高血圧合併をみた 場合, 脳血管造影の際に腹部血管造影検查を同時に施 行したため, エコーや造影 CT を行わずに血管造影で 診断を行った児が 1 例あった。両側に病変を認めたの は 2 例で, 入口部病変が 3 例, 主幹部病変は 5 例であっ た. 残りの 1 例は腹部血管造影時に左腎動脈が全く描 出されなかった。

薬物治療は全例に行い, $2 \sim 5$ 種類の降圧薬を使用 した. 初回観血的治療介入時期は 18 カ月〜 13 歳で, 中央值は 7 歳であり, ステント留置を含むカテーテル 治療は 19 回, 8 例に施行した。バルーン血管形成術は 5 例で反復して行い, 再介入までの期間は $4 \sim 24$ カ月 であった，ステント留置は 5 例に施行し, バルーン血 管形成術直後に再狭窄を来したためステント留置を要 したのは 4 例であった。 ステントは CYPHER ${ }^{\circledR} 2.5 \mathrm{~mm}$, PALMAZ $^{\circledR}$ Genesis $^{\mathrm{TM}} 4 \mathrm{~mm}, 5 \mathrm{~mm}$ (ともにジョンソン・エ ンドジョンソン株式会社製)を使用した. 1 例はカッ ティングバルーンによる血管形成術を含むカテーテル 治療を 4 9 月月毎に 3 回施行後, 短期間に再狭窄を 反復するためステントを留置した. $2.5 \mathrm{~mm}$ のステント を使用したのは 2 例あり，1例は生後 18 カ月で留置し た例で，もう 1 例は重複腎動脈で細径の腎動脈のため 留置した例であった. 2 例ともステント留置後再狭窄 を来し, 再拡張を要した。前者は術後約 1 年半後に閉 塞し, 腎摘出術に至った。 ステント留置した 5 例のう 
Table 1 Clinical and radiological studies.

\begin{tabular}{|c|c|c|c|c|c|c|c|}
\hline No & $\begin{array}{l}\text { Age (years), } \\
\text { disease }\end{array}$ & $\begin{array}{c}\text { Antihypertensive } \\
\text { drugs at PTRA } \\
\text { or surgery }\end{array}$ & $\begin{array}{l}\text { Age at PTRA or } \\
\text { surgery (years) }\end{array}$ & Arteriography & Intervention & Results & $\begin{array}{l}\text { Follow } \\
\text { up } \\
\text { (years) }\end{array}$ \\
\hline 1 & $\begin{array}{l}\text { 4, Moyamoya } \\
\text { disease }\end{array}$ & 4 & 1.5 & $\begin{array}{l}\text { Mid-vessel stenosis } \\
\text { in LRA }\end{array}$ & $\begin{array}{l}\text { PTRA (stent) } \\
\text { PTRA } \\
\text { nephrectomy }\end{array}$ & $\begin{array}{l}\text { Improved } \\
\text { Improved } \\
\text { Improved }\end{array}$ & 2 \\
\hline 2 & $\begin{array}{l}\text { 11, Moyamoya } \\
\text { disease }\end{array}$ & 5 & 2 & $\begin{array}{l}\text { Mid-vessel stenosis } \\
\text { in bilateral RA }\end{array}$ & PTRA & Improved & 8 \\
\hline 3 & 7 & 2 & 4 & $\begin{array}{l}\text { Mid-vessel stenosis } \\
\text { in LRA }\end{array}$ & $\begin{array}{l}\text { PTRA } \\
\text { PTRA }\end{array}$ & $\begin{array}{l}\text { Improved } \\
\text { Improved }\end{array}$ & 3 \\
\hline 4 & 10 & 4 & 4 & $\begin{array}{l}\text { No visualization of } \\
\text { the LK }\end{array}$ & nephrectomy & Cured & 5 \\
\hline 5 & 14 & 3 & 7 & $\begin{array}{l}\text { Ostial stenosis in } \\
\text { RRA }\end{array}$ & $\begin{array}{l}\text { PTRA } \\
\text { RRA reconstruction } \\
\text { PTRA }\end{array}$ & $\begin{array}{c}\text { Failure } \\
\text { Improved } \\
\text { No change }\end{array}$ & 6 \\
\hline 6 & $\begin{array}{l}\text { 13, Moyamoya } \\
\text { disease, } \\
\text { bilateral } \\
\text { double RA }\end{array}$ & 2 & 8 & $\begin{array}{l}\text { Ostial stenosis in } \\
\text { right lower RA }\end{array}$ & $\begin{array}{l}\text { PTRA } \\
\text { PTRA (cutting balloon) } \\
\text { PTRA } \\
\text { PTRA (stent) } \\
\text { PTRA } \\
\text { PTRA }\end{array}$ & $\begin{array}{l}\text { Improved } \\
\text { Improved } \\
\text { Improved } \\
\text { Improved } \\
\text { Improved } \\
\text { Improved }\end{array}$ & 4 \\
\hline 7 & $\begin{array}{l}\text { 17, Moyamoya } \\
\text { disease }\end{array}$ & 3 & 11 & $\begin{array}{l}\text { Ostial stenosis in } \\
\text { bilateral RA }\end{array}$ & $\begin{array}{l}\text { PTRA (stent) } \\
\text { PTRA }\end{array}$ & $\begin{array}{l}\text { Improved } \\
\text { No change }\end{array}$ & 5 \\
\hline 8 & 14 & 2 & 12 & $\begin{array}{l}\text { Mid-vessel stenosis } \\
\text { in LRA }\end{array}$ & PTRA (stent) & Improved & 2 \\
\hline 9 & $\begin{array}{l}19, \\
\text { Neurofibrom } \\
\text { atosis }\end{array}$ & 3 & 13 & $\begin{array}{l}\text { Mid-vessel stenosis } \\
\text { in LRA }\end{array}$ & $\begin{array}{l}\text { PTRA (stent) } \\
\text { PTRA } \\
\text { PTRA } \\
\text { LRA reconstruction }\end{array}$ & $\begin{array}{l}\text { Improved } \\
\text { No change } \\
\text { No change } \\
\text { Improved }\end{array}$ & 5 \\
\hline
\end{tabular}

ち 4 例は再拡張を要した. 外科治療は 4 例に施行し, 1 例 は脾動脈グラフトを用いてバイパス術を行い, 1 例は 狭窄部位を切除して端々吻合した。腎摘出術は 2 例に 施行し, 初回治療で腎摘出術を施行したのは 1 例で あった。

カテーテル治療の結果は, 治癒はなく, 改善が 14 回, 降圧効果なしが 4 回, 無効が 1 回であった。一方, 外科 治療の結果は腎摘出術を施行した 1 例が治癒で, 改善 が 3 例であった，無効の 1 例は, バルーン血管拡張術 を施行したが狭窄が硬く waist が消失せずバルーンが 破裂してバルーンカテーテル断端が腎動脈内に残留し たため外科治療を行った(Table 1).

治療後のフォローアップは, 腎臟摘出術を施行した 1 例を除いて定期的な腎エコーにて行い，7例で両腎の 大きさに差を認めないが, バルーン血管形成術を反復 して行いステントを留置した重複腎動脈の 1 例だけは 患側腎サイズが徐々に縮小してきている.

\section{考察}

腎血管性高血圧は小児の高血圧の 5 〜 10\%を占め治 療可能な高血圧であるが, 小児ではまだ治療成績に課 題がある。成人では動脈硬化性腎動脈狭窄 (主に入口部 病変)にはステント留置, 線維筋性異形成にはバルーン 血管形成術が勧められている。線維筋性異形成に対す るカテーテル治療の成績は良好であるが, 動脈硬化性 腎血管性高血圧では腎実質病変や全身の動脈硬化, そ のほか代謝性疾患などが病態に関係しており, 狭窄の 解除が必ずしも腎機能保護や高血圧の改善につながる わけではない3). 成人と違い小児では原疾患が動脈硬化 以外であることや，高血圧に曝されている期間が短く， 腎機能は悪くないことが多いため適切に治療すると予 後はよい.しかしながら小児では成長に伴う腎臟・腎 血管の発育や, 成人に比べ長期的な予後を考慮する必 要がある。 


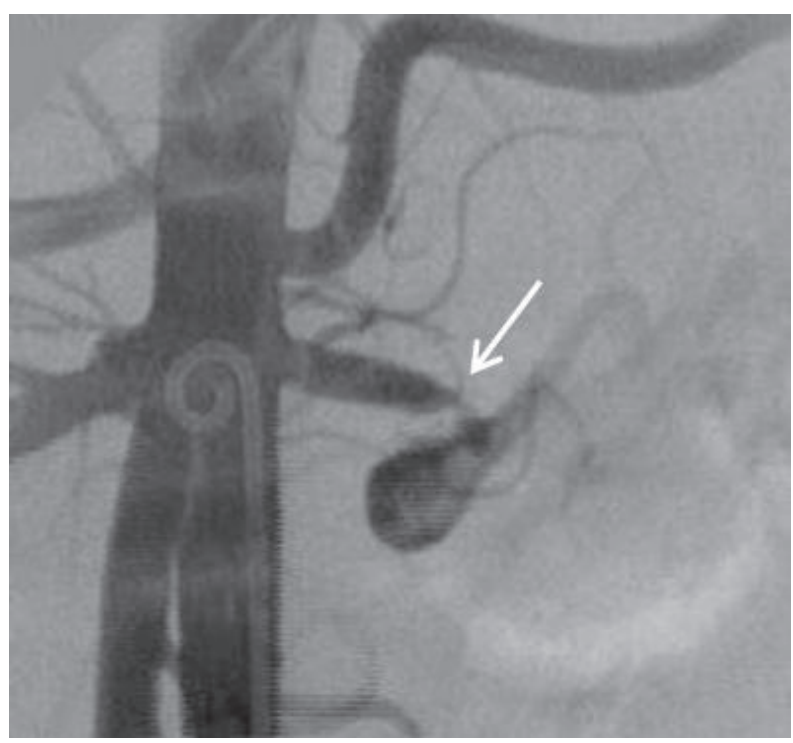

Fig. 1 Patient 9: Angiography of the left renal artery stenosis before stent implantation.

小児例での外科治療の成績は良好で, $90 \%$ 以上で治 癒もしくは改善の効果が得られている4,5). 以前は伏在 静脈をグラフトとして利用していたが, 瘤状拡大を来 す例があるため現在ではバイパス術には動脈グラフト を使用し, 血行再建術では腎動脈 - 大動脈直接吻合術 が行われる ${ }^{4}$. 外科治療は腎血管径が成人に近くなる 4 〜 5 歳まで待機できたほうがよいとされるため ${ }^{5)}$, 体格 の小さい患者の場合のカテーテル治療は, 体格が大き くなり根治的手術が行われるまでに腎機能低下を来さ ないようにすることを目的とした治療と考えている.

小児の腎血管性高血圧に対するバルーン血管形成術 の成績は, 基礎疾患や狭窄の形態にもよるが改善以上 の効果が得られる確率は28～94\% と報告されてい

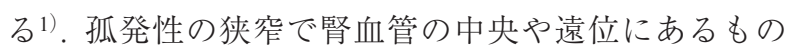
は, 複数の狭窄や長い狭窄, 入口部の狭窄より成績が よい. 線維筋性異形成, 動脈炎, mid-aortic syndrome で の成績は比較的良好で, 神経線維腫症に合併するもの の成績はよくない6). 当院で経験した神経線維腫症の児 では腎動脈が蛇行し, また瘤形成が認められ, カテー テル治療の適応外であると思われたが, 家族の強い希 望を受けてバルーン血管形成術を施行した、ステント を留置したが瘤の縮小には至らず，またステント前後 に再狭窄を生じて改善は限定的であったため, 最終的 には手術療法を施行した(Fig. 1).

バルーン血管形成術術後に問題となるのは再狭窄 で，小児の腎動脈での再狭窄率は $7.4 \sim 26 \%$ と報告さ れている6,7).成人での腎動脈に対するバルーン血管形 成術術後の再狭窄率は $26 \%$ で 8 ，ほぼ同等である，当院
でステント留置前に再狭窄のためバルーン血管形成術 を繰り返し要した症例では, 腎動脈の狭窄部が $0.9 \mathrm{~mm}$, 遠位部で $2.2 \mathrm{~mm}$ と細径であった. 成人の冠動脈の報告 と比較してみると, 冠動脈血管径を問わない場合のバ ルーン血管形成術での再狭乍率は $32 \%$ で9)，血管径 $3 \mathrm{~mm}$ 未満の冠動脈に対するバルーン血管形成術の再狭 窄率は $55 \%$ と高く ${ }^{10)}$, 径が細くなると再狭窄率が上が るために繰り返しバルーン血管形成術が必要となった と考えられた (Fig 2).

ステント留置後の問題点としてステント内再狭窄が ある. 小児の腎動脈に対するステント留置の報告は少 ないが, Shroff らの報告によるとステント内再狭窄は $36.8 \%$ であ. 成人の腎動脈に㧍ける再狭窄率は $14.6 \%$ であり ${ }^{11)}$, 成人と比較すると高い。成人の冠動脈ステ ントに打ける再狭窄率は $35.4 \%$ であり ${ }^{12)}$, 小児の腎動 脈に打ける再狭窄率とよく似ているのは血管径がほぼ 同様であるからではないかと Shroffらは推測してい る。当院ではステントを留置した 5 例のうち 4 例にバ ルーンによる再拡張を施行した。再介入率の高い原因 として当院では経過観察をエコー検查で行っている が, ステント留置後血圧が上昇してきた際にはステン 卜内狭窄を疑い, 狭窄が重度になってからでは再拡張 が困難になると考えられるため, 可及的早期に血管造 影を行って評価し, 狭窄を認めた場合には引き続いて バルーンによる再拡張を行ったためと考えられる.

当院で経験した腎血管性高血圧の患児は, もやもや 病である割合がほかの報告に比べ高かった。もやもや 病には約 8\%の確率で腎血管性高血圧を合併する ${ }^{13)}$. もやもや病に腎血管性高血圧が合併した場合には, 腎 血管性高血圧の術後に血圧が低下して脳虚血症状が悪 化することがあるため, もやもや病の治療を先に行う べきとされている14). 2 件の報告では, もやもや病に合 併した小児の腎血管性高血圧のカテーテル治療の成績 は 5 例中 4 例で治癒もしくは改善の効果を得てい る ${ }^{13,15)}$ が, $4 \sim 12$ 歳の症例で比較的体格が大きな症例 であったと推察される。

当院の症例で細径の腎動脈に対して介入したものの 1 例は, 16 力月で診断され 18 力 (体重 $10.8 \mathrm{~kg}$ ) でバルー ン血管形成術を施行した。腎動脈は細径で近位部が $2.0 \mathrm{~mm}$ しかなく, バルーンで拡大直後にほぼ閉塞した ためステント留置に至った.もう 1 例はもやもや病で 脳梗塞を反復して寝たきりの状態の児で, 10 歳では あったが体重は $17.9 \mathrm{~kg}$ であり, かつ両側重複腎動脈で あったため腎動脈は細径で, 右下腎動脈の狭窄部は $0.9 \mathrm{~mm}$, 遠位部で $2.2 \mathrm{~mm}$, 対側の腎動脈は $1.8 \mathrm{~mm}$, 同側 上位の腎動脈は $1.6 \mathrm{~mm}$ であった(Fig. 3)。細径でもバ 


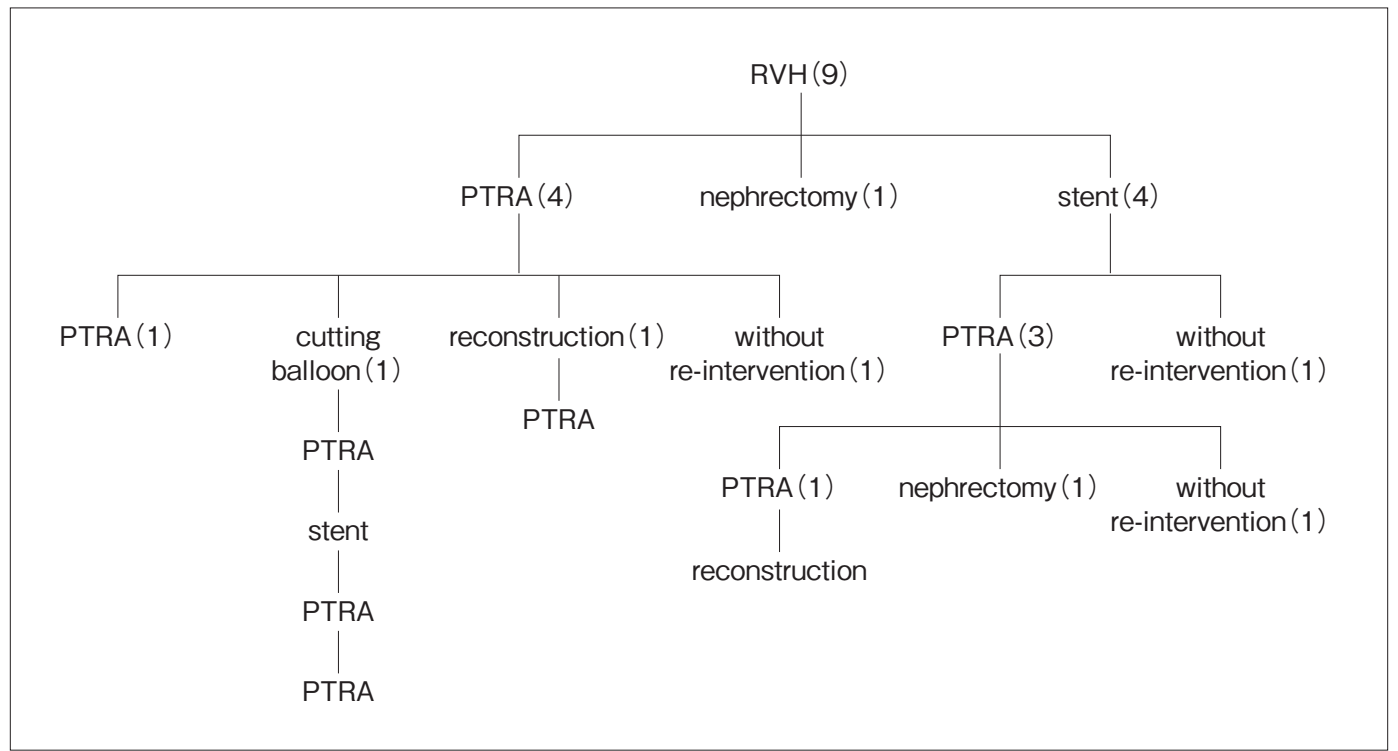

Fig. 2 Outcome of percutaneous transluminal renal angioplasties (PTRA). $\mathrm{RVH}$ : renovascular hypertension

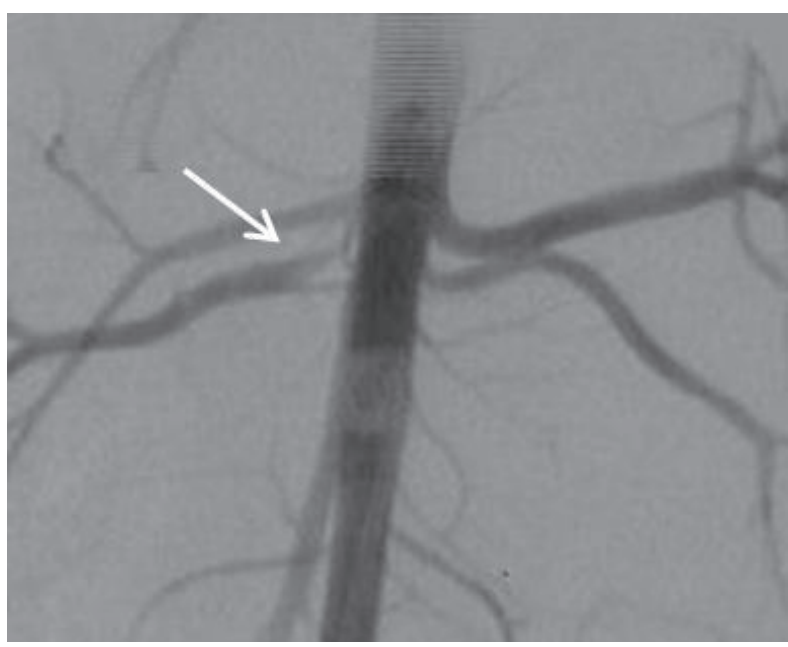

Fig. 3 Patient 6 : Angiography of the right renal artery stenosis before balloon angioplasty.

ルーン血管形成術のみで改善を得られた場合はその後 介入なく血圧がコントロールできることもあるが, 細 径のステント留置に至った場合は再狭窄により再介入 が必要となり治療効果に限りがあった。

\section{結語}

カテーテル治療，外科治療ともに短期の成績はおお むね良好であったが, 幼児や重複腎動脈で細径のステ ント留置に至った場合は, 再狭窄に対して繰り返し介 入が必要となり, 治療に難渋した。

\section{【参考文献】}

1) Tullus K, Brennan E, Hamilton G, et al: Renovascular hypertension in children. Lancet 2008; 371: 1453-1463

2) Bayazit AK, Yalcinkaya F, Cakar N, et al: Reno-vascular hypertension in childhood: a nationwide survey. Pediatr Nephrol 2007; 22: 1327-1333

3) Guidelines for management of peripheral arterial occlusive disease. Circ J 2009; 73 : 1507-1569

4) Stanley JC, Criado E, Upchurch GR Jr, et al: Pediatric renovascular hypertension: 132 primary and 30 secondary operations in 97 children. J Vasc Surg 2006; 44: 1219-1228

5) Piercy KT, Hundley JC, Stafford JM, et al: Renovascular disease in children and adolescents. J Vasc Surg 2005; 41 : 973-982

6) König K, Gellermann J, Querfeld U, et al: Treatment of severe renal artery stenosis by percutaneous transluminal renal angioplasty and stent implantation: review of the pediatric experience: apropos of two cases. Pediatr Nephrol 2006; $21: 663-671$

7) Shroff R, Roebuck DJ, Gordon I, et al: Angioplasty for renovascular hypertension in children: 20-year experience. Pediatrics 2006; 118: 268-275

8) Leertouwer TC, Gussenhoven EJ, Bosch JL, et al: Stent placement for renal arterial stenosis: where do we stand? A meta-analysis. Radiology 2000; 216: 78-85

9) Erbel R, Haude M, Höpp HW, et al: Coronary-artery stenting compared with balloon angioplasty for restenosis after initial balloon angioplasty. Restenosis Stent Study Group. N Engl J Med 1998; 339: 1672-1678

10) Savage MP, Fischman DL, Rake R, et al: Efficacy of coronary stenting versus balloon angioplasty in small 
coronary arteries. Stent Restenosis Study (STRESS) Investigators. J Am Coll Cardiol 1998; 31: 307-311

11) Zähringer M, Sapoval M, Pattynama PM, et al : Sirolimuseluting versus bare-metal low-profile stent for renal artery treatment (GREAT Trial) : angiographic follow-up after 6 months and clinical outcome up to 2 years. J Endovasc Ther $2007 ; 14: 460-468$

12) Moses JW, Leon MB, Popma JJ, et al: Sirolimus-eluting stents versus standard stents in patients with stenosis in a native coronary artery. N Engl J Med 2003; 349 : 1315-1323
13) Choi Y, Kang BC, Kim KJ, et al: Renovascular hypertension in children with moyamoya disease. J Pediatr 1997; 131: 258-263

14) 車田宏之, 熊崎寿美, 海野 健, ほか: 腎血管性高血圧症 を合併したモヤモヤ病の1男児例 獨協医誌 $1995 ; \mathbf{1 0}$ : 637-642

15) Yamada I, Himeno Y, Matsushima Y, et al: Renal artery lesions in patients with moyamoya disease: angiographic findings. Stroke 2000; 31: 733-737 